\title{
A simple hydrothermal cell for synthesis at moderate temperatures and pressures
}

\author{
J A K TAREEN, B BASAVALINGU, M A SHANKARA and ALI \\ REZA FAZELI \\ Mineralogical Institute, Manasagangotri, Mysore 570006, India \\ MS received 27 February 1986; revised 7 April 1986
}

\begin{abstract}
A simple hydrothermal cell without threaded parts has been developed for routine synthesis of materials at moderate temperatures (upto $500^{\circ} \mathrm{C}$ ) and pressures (upto $5 \mathrm{~kb}$ ). The sealing of the fluid pressure in the cell has been achieved with a cone-seat arrangement, but the sealing pressure has been through a hydraulic ram instead of a threaded cap. Experience showed that this cell is more convenient for rapid and routine experimentation.
\end{abstract}

Keywords. Hydrothermal cell; material synthesis.

\section{Introduction}

The hydrothermal method has increasingly been recognised as a potential technique for synthesis of inorganic materials, crystal growth (Laudise 1973) and even for the large scale preparation of pure ultrafine oxides (Stambaugh 1982). To mineralogists, hydrothermal investigation of the mineral reactions is of immense value to understand their paragenesis and the conditions of their formation. Hydrothermal reactors employing different kind of sealing systems (Morey and Ingerson 1937; Walker and Buchler 1950; Bridgman 1914; Roy and Tuttle 1956) have been in use for the past few decades. The authors have also designed and fabricated such reactors in this laboratory for hydrothermal studies. All these reactors invariably contain threaded parts and call for an extremely precise machining. Except for the Tuttletype cold seal reactors, other systems such as Bridgman type etc also need the use of deformable gaskets and such gaskets are to be replaced after every experiment. Further, all these hydrothermal reactors which employ threaded caps for sealing, need frequent machining for cleaning and dressing the threads.

The high cost for precision machining and the considerable loss of time due to the frequently required machining of these reactors was a disadvantage for the routine experimentation. This prompted the authors to develop a more simpler and low cost cell which was found to be extremely convenient for routine exploratory runs under moderate temperatures and pressures. This paper is a report of this cell.

\section{The new hydrothermal cell}

As shown in figure $1^{*}$, the cell consists of two parts:

(a) the lower part is the furnace assembly with supporting shell made from mild steel

\footnotetext{
*Engineering drawing can be obtained from the author on request.
} 


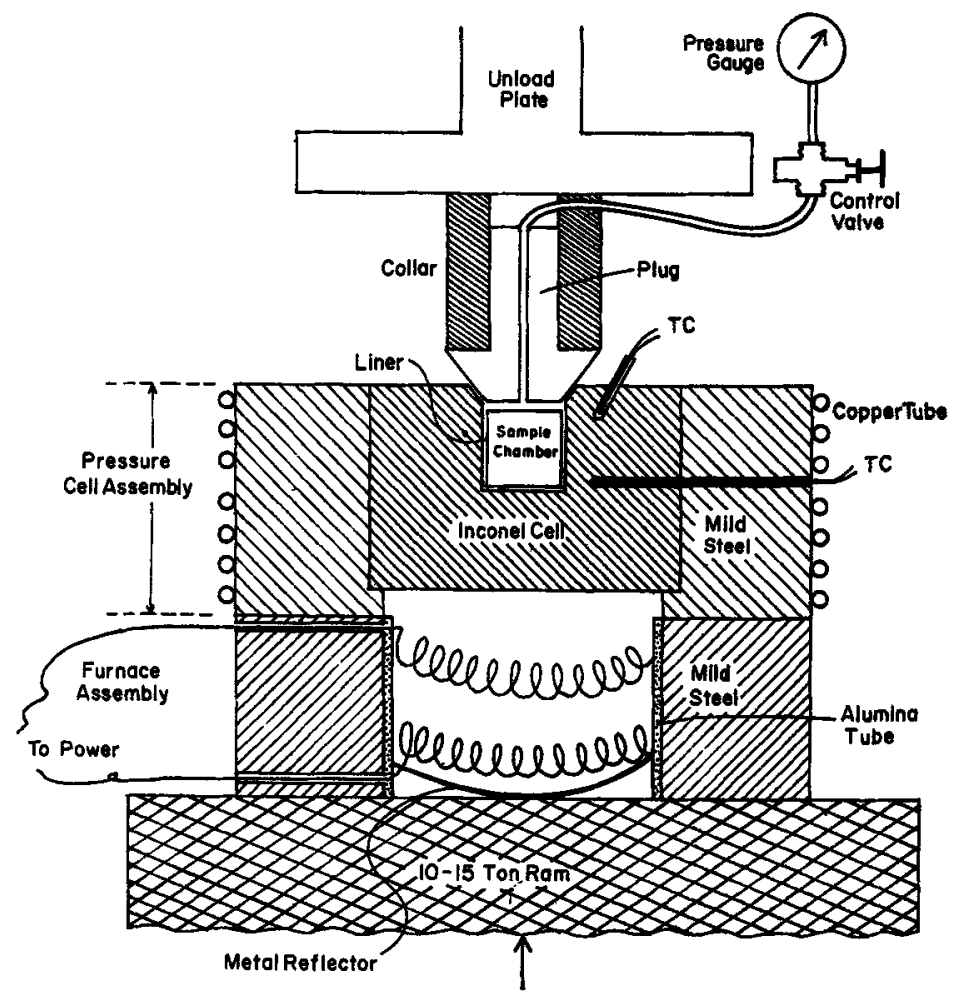

Figure 1. The new hydrothermal cell (scale 1:1).

or EN-18 series. The resistance heating coil is wound from kanthal AI placed spirally inside the ceramic sleeve tightly fitted into the supporting shell. The coil power should be limited to $30 \mathrm{amp}$ and $50 \mathrm{~V}$ to raise the temperature of the sample chamber to a maximum of $500^{\circ} \mathrm{C}$. The power supply is through a voltage stabilizer and a $50 \mathrm{~A}$ variac.

(b) the upper part of the system consists of the pressure cell made from inconel. This high pressure cell has been tightly heat-fitted into another concentric shell of mild steel or EN-18 series. The pressure cell (10 cc capacity) has been provided with a cone-seating closure. The seating cone is made from stainless steel 316 , preferably hardened by heating upto $400^{\circ} \mathrm{C}$ and quenching in water.

If water or any non-corrosive fluid is used as mineralizer, the cell can be used without a protective liner in the sample chamber. But, with corrosive fluid, the charge has to be encapsulated in a noble metal ampoule. A small silver liner can also be used in which case the pressure generated inside the liner has to be balanced by generating equal pressure outside the liner by using appropriate percent fill of water. The pressure generated in the cell depends on the initial fluid filled into the cell. For example, if $80 \%$ of free volume of the cell is filled with $\mathrm{H}_{2} \mathrm{O}$ at $500^{\circ} \mathrm{C}$, it generates about 3200 bars fluid pressure. The P-V-T diagrams for some fluids such as $\mathrm{H}_{2} \mathrm{O}$ (Kennedy 1950), $\mathrm{CO}_{2}$ (Kennedy 1954), $\mathrm{HCl}$ (Rau and Kutty 1972), etc are reported which make the pressure reading straightforward. Alternatively, the fluid pressure 
could also be read on Bourden gauge connected to the sample chamber through a stainless steel high pressure tubing. This is possible only when the charge is encapsulated and the pressurising fluid is water or gas.

The quenching of the vessel to arrest the reaction in equilibrium can be achieved by flushing compressed chilled air or water through the copper tubing on the outer shell. The quenching time to cool from $500^{\circ} \mathrm{C}$ to ambient by this process is about 10 minutes.

The cell, after being charged with the sample is placed between the two rams of hand operated hydraulic press of 15 ton capacity (figure 2) and pressed with about 5-6 tons of load. The sealing thus achieved will be effective to retain upto $5 \mathrm{~kb}$ pressure inside the chamber. The use of hydraulic press eliminates the threaded parts in the system which makes the sealing as well as opening of the cell considerably simple and rapid, thus reducing the changing time to about 15-20 minutes from one experiment to another. Further, the concentric shell arrangement ensures safety against any rupture. The expected life of the cell is about $10,000 \mathrm{hr}$. However, owing to the reasonably low cost of the cell (Rs. 500 to 600) it enables any laboratory to afford a few spare cells and change them after about $2000 \mathrm{hr}$ of running use. The authors, in fact, have been using a cell for over $2000 \mathrm{hr}$ which still does not call for replacement or re-machining.

Finally, the authors would like to emphasize that the new sealing device suggested in this report is not a total substitute to the other type of reactors but it is an extremely convenient and low cost device for rapid experimentation at moderate hydrothermal conditions.

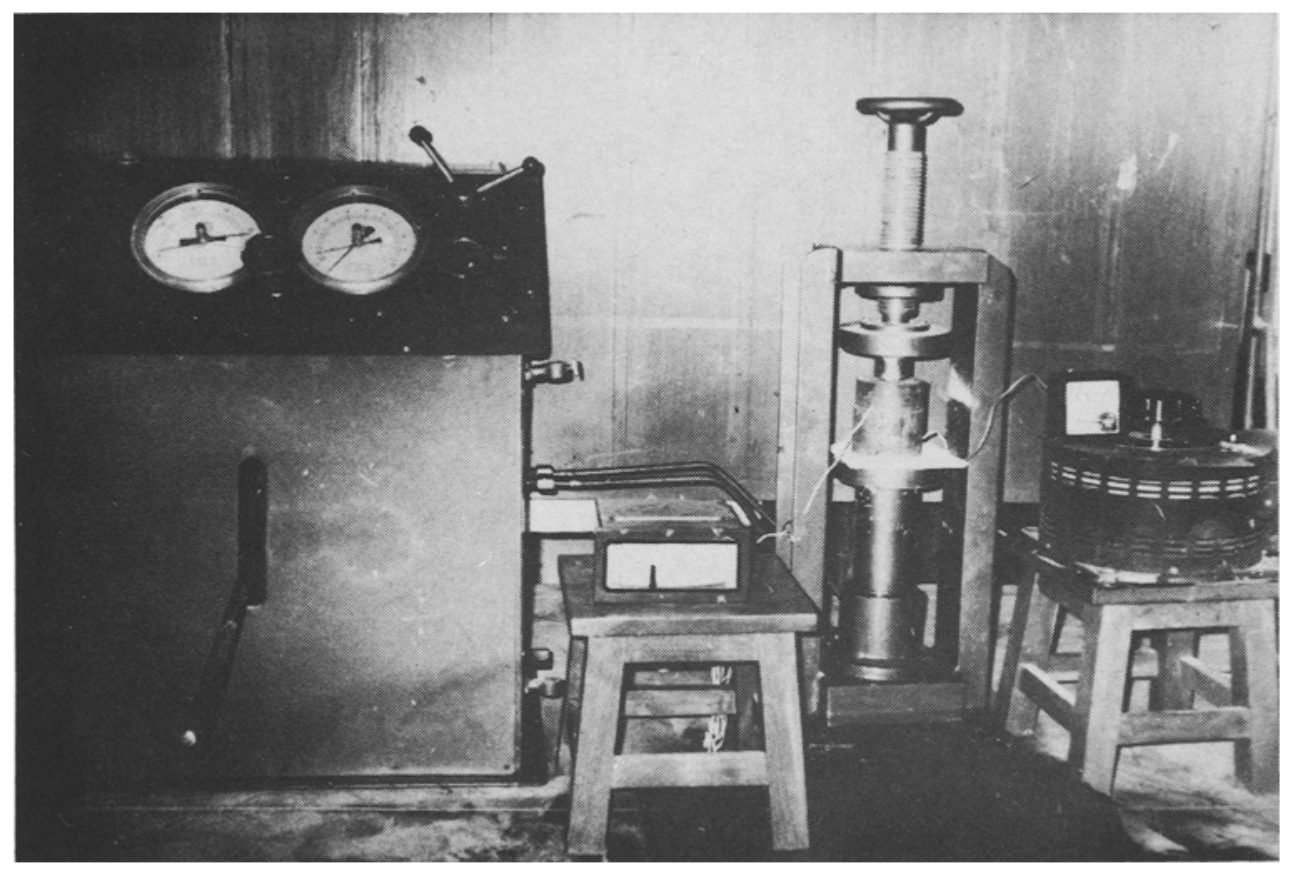

Figure 2. Positioning of the cell between the rams of the hydraulic press. 


\section{Acknowledgements}

The authors thank Prof. V Venkatachalapathy for encouragement. The skilful machining work of $\mathrm{Mr}$ Nadeem-ur-Rehman-Khan is acknowledged.

\section{References}

Bridgman P W 1914 Proc. Am. Acad. Arts Sci. 49625

Kennedy G C 1950 Am. J. Sci. 248540

Kennedy G C 1954 Am. J. Sci. 252225

Laudise R A 1973 Crystal growth: An introduction (The Netherlands: North Holland Publishing Co.) p 162 Morey G W and Ingerson E 1937 Am. Mineral. 221121

Rau H and Kutty T R N 1972 Ber. Bun. Ges. Phys. Chem. 76645

Roy R and Tuttle O F 1956 Phys. Chem. Earth 1138

Stambaugh E P 1982 Proc. First Int. Symp. Hydrothermal Reaction (Japan: Gakujutsu Bunken Fukyu-Kai) p 859

Walker A C and Buchler E 1950 Ind. Eng. Chem. 421369 